\title{
Determinan Finansial dan Nonfinansial Corporate Social Responsibility Disclosure
}

\author{
I Nyoman Adi Wiyarna ${ }^{1}$ \\ Fakultas Ekonomi dan Bisnis \\ Universitas Udayana, Indonesia. \\ Email: adiwiyarna@gmail.com
}

\author{
I Putu Sudana ${ }^{2}$ \\ Fakultas Ekonomi dan Bisnis \\ Universitas Udayana, Indonesia.
}

\begin{abstract}
ABSTRAK
Penelitian ini dilakukan pada perusahaan pertambangan yang terdaftar di Bursa Efek Indonesia tahun 2013-2017. Sampel dalam penelitian ini ditentukan dengan metode nonprobability sampling dengan teknik purposive sampling, dan sampel yang diperoleh dalam penelitian ini berjumlah 13 perusahaan dengan 65 pengamatan. Teknik analisis data yang digunakan dalam penelitian ini adalah teknik analisis regresi berganda. Hasil penelitian ini menunjukkan bahwa variabel profitabilitas, leverage, kepemilikan manjerial, firm's growth dan media exposure berpengaruh positif terhadap pengungkapan Corporate Social Responsibility. Hal ini menunjukkan bahwa adanya sorotan terhadap perusahaan yang memiliki profitabilitas tinggi, perusahaan yang high-leveraged, perusahaan yang memiliki pertumbuhan yang tinggi, kepemilikan manajerial yang besar dan tekanan media yang tinggi sehingga dapat dimengerti perusahaan tersebut akan mengungkapkan Corporate Social Responsibility lebih banyak dan detail untuk mengurangi tekanan tersebut.
\end{abstract}

Kata Kunci : Profitabilitas; Leverage; Kepemilikan Manajerial; Firm's Growth; Media Exposure; CSR.

\section{Financial Determinants and Non-Corporate Corporate Social Responsibility Disclosure}

\section{ABSTRACT}

This research was conducted at mining companies listed on the Indonesia Stock Exchange in 2013-2017. The sample in this study was determined by nonprobability sampling method with purposive sampling technique, and the samples obtained in this study amounted to 13 companies with 65 observations. The data analysis technique used in this study is multiple regression analysis techniques. The results of this study indicated that the variables of profitability, leverage, managerial ownership, firm's growth and media exposure have a positive effect on disclosure of Corporate Social Responsibility. This shows that there is an exposure on high profitability companies, high-leveraged companies, high firm's growth companies, large managerial ownership and high media pressure so that it can be understood that the company will disclose more detailed informtion about Corporate Social Responsibility to reduce the pressure.

Keywords: $\quad$ Profitability; Leverage; Mnagerial Ownership; Firm's Growth; Media Exposure; CSR.

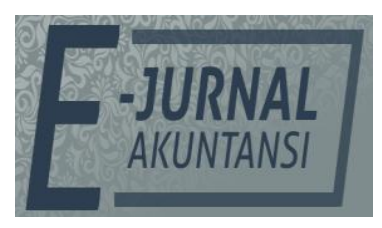

E-JA

e-Jurnal Akuntansi e-ISSN 2302-8556

Vol.298 No. 1

Denpasar, Oktober

2019

Hal. 292-307

Artikel masuk:

20 Agustus 2019

Tanggal diterima: 02 September 2019 


\section{PENDAHULUAN}

Kontribusi sektor industri yang menguntungkan telah terbukti signifikan bagi pertumbuhan ekonomi nasional. Namun, aktivitas industri juga tidak lepas dari semakin luasnya eksploitasi sumber daya alam, bahkan beberapa perusahaan menyebabkan degradasi lingkungan yang parah. Banyak perusahaan asing dan lokal di Indonesia bersaing dalam memajukan usahanya untuk membuat bisnis mereka tumbuh secara substansial. Hal ini dipicu oleh pembukaan Asean Economic Community (AEC). Kondisi ini dapat dianalogikan dengan pisau bermata dua. Artinya, di satu sisi korporasi mampu memenuhi kebutuhan masyarakat dan pada saat yang sama meningkatkan kekayaan pemegang saham. Akan tetapi, di sisi lain semakin banyak pencemaran lingkungan yang dihasilkan oleh aktivitas perusahaan.

Contoh-contoh fenomena pencemaran lingkungan yang disebabkan oleh aktivitas industri perusahaan pertambangan, antara lain limbah pertambangan emas PT Nusa Halmahera Mineral di Halmahera, Maluku Utara. Penelitian yang dilakukanoleh Institut Pertanian Bogor (IPB) menemukan bahwa beberapa jenis biota laut terkontaminasi dengan bahan berbahaya, seperti sianida dan merkuri. Fenomena yang serupa ditemukan di Samarinda. Limbah pertambangan batubara PT Arutmin di Samarinda yang dianggap melanggar prosedur menyebabkan warga kehilangan mata pencaharian sebagai petani karena lahan mereka ditutupi oleh limbah bercampur dengan lumpur sehinggatidak bisa ditanami. Limbah pertambangan batubara PT Kaltim Prima Coal telah membuat Sungai Sangatta menjadi sangat kotor dan terkontaminasi dengan limbah sementara sungai Sangatta digunakan oleh masyarakat Sangatta untuk kebutuhan sehari-hari. Limbah pertambangan emas PT Antam yang aktivitas perusahaannya di hulu memiliki dampak negatif pada penduduk setempat seperti penyakit pernapasan dan keracunan merkuri akut. Limbah pertambangan emas, perak, dan tembaga PT Freeport Indonesiajuga menyebabkan kerusakan lingkungan.Badan Pemeriksa KeuanganRepublik Indonesia mencatat potensi kerugian akibat kerusakan lingkungan mencapai 185 miliar rupiah.

Peristiwa tersebut telah membuka mata Indonesia tentang pentingnya Corporate Social Responsibility (CSR). Selain itu, menurut Performance Index lingkungan yang merupakan indikator kinerja di sepuluh kategori masalah yang meliputi kesehatan lingkungan dan vitalitas ekosistem. Dalam hal ini, Indonesia berada di peringkat 133 dari 180 negara yang seharusnya menjadi wake-up call bagi pemerintah Indonesia untuk lebih memperhatikan hal ini (Yale Cetre for Enviromental Law \&Policy, 2018).

Kadang-kadang perusahaan mengabaikan CSRatas dasar kelangsungan hidup perusahaan tidak berhubungan dengan lingkungan sosialnya (Reni \& Anggraini, 2006). CSR merupakan suatu jaminanagar perusahaan tidak hanya berfokus pada kepentingan pemegang saham, tetapi juga sebagai bentuk pengawasan dari tindakan penipuan dalam praktik bisnis, yaitu masyarakat lokal, pekerja, LSM, pemerintah, konsumen, dan lingkungan (Kholis \& Maksum, 2003). Epstein \& Friedman (1994) menyatakan bahwa informasi sosial dilaporkan dalam laporan tahunan menjadi daya tarik utama bagi investor individu karena mengandung informasi tentang sosial, lingkungan, dan keuangan. 
Informasi tentang kinerja perusahaan merupakan elemen penting bagi investor dan pebisnis karena informasi pada dasarnya menyajikan data, catatan, gambar, apakah itu dari masa lalu atau untuk keadaan sekarang dan masa depan untuk kelangsungan hidup perusahaan dan bagaimana pasar memengaruhi. Informasi yang lengkap, relevan, akurat, dan tepat waktu adalah informasi yang dibutuhkan oleh investor di pasar modal sebagai alat analisis untuk membuat keputusan investasi. Dalam teori Signaling, dinyatakan bahwa informasi yang dipublikasikan akan memberikan sinyal bagi investor dalam membuat keputusan investasi. Artinya, kelengkapan pengungkapan laporan keuangan berkaitan erat dengan pengambilan keputusan investasi pihak luar (investor dan kreditor) perusahaan (Jogiyanto, 2017). Berdasarkan teori Signaling ini, perusahaan secara sukarela akan mengungkapkan informasi penting kepada pihak eksternal untuk menjadi acuan dalam membuat keputusan investasi. Salah satu hal yang penting untuk diungkapkan adalah CSR.

Konsep CSR telah menjadi dasar pemikiran para pembuat kebijakan untuk waktu yang lama. Buku karangan Howard Bowen yang berjudulSocial Responsibilities of the Businessman yang diterbitkan pada tahun 1953 merupakan tonggak sejarah CSR modern. Buku Bowen memberikan landasan awal untuk pengenalan kewajiban pelaku usaha untuk menetapkan tujuan bisnis yang selaras dengan tujuan dan nilai-nilai masyarakat (Nasutionet al., 2011). Keberadaan perusahaan sebagai bagian dari masyarakat seharusnya memberikan manfaat bagi masyarakat sekitarnya. Di samping itu, juga wajib memberikan kontribusi kepada masyarakat setempat karena dampak dari setiap industri yang berbeda. Hal ini sejalan dengan teori Stakeholder bahwa perusahaan tidak hanya merupakan suatu entitas yang beroperasi untuk kepentingan sendiri, tetapi juga harus mampu memberikan manfaat kepada para pemangku kepentingan (Ajilaksana, 2011).

Penelitian ini memiliki tujuan untuk mendapatkan bukti empiris mengenai profitabilitas, leverage, kepemilikan manjerial, firm's growth, dan media exposure pada pengungkapan CSR perusahaan. Penelitian ini dapat memberikan informasi mengenai faktor-faktor penentu yang dianggap oleh indsutri pertambangan yang terdaftar di Bursa Efek Indonesia untuk periode 2013-2017 pada pengungkapkan Corporate Social Responsibility yang berkaitan dengan teori Stakeholder, teori Signaling, dan teori pendukung lainnya yang terdapat dalam penelitian ini. Penelitian ini juga menjadi acuan pada penelitian berikutnya terkait dengan Corporate Social responsibility Disclosureatau variabel lainnya yang terkait.

Hasil penelitian ini juga dapat memberikan kontribusi kepada perusahaan terutama manajemen perusahaan dan pengguna laporan keuangan lainnya dalam memahami dan memperluas pelaksanaan faktor pengungkapan tanggung jawab sosial perusahaan dalam industri pertambangan. Selain itu, hasil penelitian ini juga dapat menjadi sumber informasi bagi investor dan calon investor mengenai faktor-faktor penentu Corporate Social Responsibility dan pengungkapan sebagai pertimbangan dalam pengambilan keputusan investasi.

Teori stakeholder menyatakan bahwa perusahaan bukanlah entitas yang hanya beroperasi untuk kepentingan sendiri tetapi juga harus mampu memberikan manfaat bagi para pemangku kepentingan. Menurut Ghozali \& 
Chariri(2007), keberadaan perusahaan sangat dipengaruhi oleh dukungan yang diberikan oleh stakeholder kepada perusahaan. Teori Stakeholder digunakan untuk menjelaskan hubungan antara masyarakat dan perusahaan. Hal itu perlu karena perusahaan harus mempertimbangkan kepentingan semua pihak atau masyarakat yang terkena dampak aksi korporasi dalam pengambilan keputusan. Menurut teori Stakeholder, meningkatnya tanggung jawab sosial perusahaan membuat perusahaan lebih menarik bagi masyarakat dan investor.

Teori Legitimasi menyatakan perilaku perusahaan dan cara yang digunakan perusahaan saat menjalankan bisnis harus berada dalam bingkai pedoman yang telah disepakati oleh masyarakat. Dalam hal ini perusahaan memiliki kontrak sosial (social contract) yang berisikan sejumlah hak dan kewajiban. Kontrak sosial ini merupakan dasar bagi legitimasi suatu bisnis. Ghozali \& Chariri (2007)menyatakan bahwa kegiatan perusahan dapat menimbulkan dampak sosial dan lingkungan. Dengan demikian, praktik pengungkapan CSR merupakan alat untuk menghindari konflik sosial dan lingkungan suatu perusahaan. Oleh karena itu, dapat dimengerti bahwa untuk mendapat legitimasi masyarakat tiap perusahaan harus melakukan pengungkapan CSR melalui publikasi informasi atau informasi yang diumumkan di media. Hal ituakan dijadikan oleh pengguna laporan keuangan sebagai sinyal buruk atau sinyal baik pada upaya pengambilan keputusan oleh pengguna laporan keuangan.

Konsep pelaporan CSR yang diprakarsai oleh ISO 26000 merupakan standar internasional yang dikembangkan untuk membantu organisasi secara efektif menilai dan menangani tanggung jawab sosial yang relevan dan signifikan terhadap misi dan visi; operasi dan proses; pelanggan, karyawan, komunitas, dan pemangku kepentingan lainnya; serta dampak lingkungan (Sabatini \& Sudana, 2019). Standar ISO 26000 memberikan panduan tentang tujuh prinsip utama yang mendasari tanggung jawab sosial, yaitu akuntabilitas, transparansi, perilaku etis, menghormati kepentingan pemangku kepentingan, menghormati aturan hukum, menghormati norma-norma perilaku internasional, dan menghormati hak asasi manusia.

Profitabilitas adalah kemampuan perusahaan untuk menghasilkan keuntungan dan mengukur tingkat efisiensi operasional dalam menggunakan aset yang dimiliki (Chen, 2011). Hal ini sangat mungkin untuk melihat perusahaan yang menguntungkan, memberikan informasi terperinci dalam rangka untuk menarik investor, dan untuk menyoroti efektivitas manajemen(Putra \& Wiagustini, 2013). Perusahaan yang menguntungkan memiliki sinyal positif terhadap stakeholders. Hal ini sejalan dengan sebagian besar penelitian sebelumnya antara lain penelitian yang dilakukan oleh Hassan \& Naser (2013) dan Felicia \& Rasmini (2015) melaporkan hubungan positif dan signifikan antara pelaporan tanggung jawab sosial perusahaan dan profitabilitas perusahaan. Dengan demikian, hipotesis pertama yang diajukan adalah sebagai berikut.

$\mathrm{H}_{1}$ :Profitabilitas berpengaruh positif pada pengungkapan CSR.

Sebuah perusahaanhigh leveraged akan diminta oleh pemberi pinjaman untuk mengungkapkan informasi lebih terperinci daripada perusahaan dengan rasio leverage yang rendah. Pemberi pinjaman meminta informasi terperinci 
sebelum memberikan pinjaman. Selain itu, bank dan organisasi pinjaman lainnya lebih cenderung untuk meminjamkan kepada perusahaan yang sukses dan terkemuka. Oleh karena itu, perusahaan yang high leveraged sangat mungkin untuk mengungkapkan informasi sosial lebih dari perusahaan lainnya untuk memenuhi harapan bank dan harapan organisasi pinjaman lainnya (Sari, 2017). Felicia \& Rasmini (2015) menunjukkan hubungan yang positif dan signifikan antara tingkat pelaporan tanggung jawab sosial perusahaan dan tingkat leverage perusaan. Artinya, semakin tinggi leverage, maka semakin tinggi pengungkapan informasi CSR. Oleh karena itu, hipotesis kedua yang diajukan adalah sebagai berikut.

$\mathrm{H}_{2}$ : Leverage berpengaruh positif pada pengungkapan CSR.

Semakin besar proporsi kepemilikan manajemen dalam perusahaan, manajemen cenderung berusaha lebih untuk kepentingan pemegang saham yang tidak lain adalah dirinya sendiri (Ross, 2002). Perusahaan yang memisahkan fungsi manajemen dengan fungsi kepemilikan akan rentan terhadap masalah keagenan. Perusahaan menggunakan laporan tahunan mereka untuk mengurangi asimetri informasi antara manajemen dan pemilik. Masalah utama dari lembaga adalah perbedaan antara pemilik dan manajer. Semakin banyak saham yang dimiliki oleh publik, semakin besar tekanan yang dihadapi perusahaan untuk mengungkapkan informasi lebih lanjut dalam laporan tahunannya. Hal ini sejalan dengan penelitian Mahadewi \& Krisnadewi (2017) dan Rahajeng (2010) bahwa kepemilikan manajerial secara positif memengaruhi hubungan antara kepemilikan saham manajerial atas pengungkapan CSR yang luas.Berdasarkan asumsi di atas, maka hipotesis ketiga yang diajukan adalah sebagai berikut.

$\mathrm{H}_{3}$ : Jumlah kepemilikan manajemen berpengaruh positif pada pengungkapan CSR.

Perusahaan yang berorientasi pada konsumen diperkirakan akan memberikan informasi mengenai CSR karena hal ini akan meningkatkan citra perusahaan (Cowenet al., 1987). Hal ini sejalan dengan teori legitimasi bahwa perusahaan dengan pertumbuhan yang tinggi akan melaporkan pengungkapan CSR sebagai suatu usaha untuk mendapat legitimasi masyarakat atau meningkatkan citra suatu perusahaan. Di samping itu, firm's growth juga merupakan suatu sinyal yang ditujukkan kepada pengguna laporan keuangan dalam pengambilan suatu keputusan terutama keputusan investasi dan akuntabilitas suatu perusahaan di mata publik dan stakeholders. Penelitian yang dilakukan Maria (2009) tidak dapat menemukan efek firm's growth pada CSR. Namun, penelitian yang dilakukan oleh Munsaidah et al.(2016) menyatakan bahwa firm's growth berpengaruh positif pada pengungkapan CSR. Berdasarkan uraian tersebut dirumuskan hipotesis keempat sebagai berikut.

$\mathrm{H}_{4}$ : Firm's Growth berpengaruh positif pada pengungkapan CSR.

Fungsi komunikasi menjadi hal yang sangat penting dalam manajemen pengungkapan CSR. Komunikasi CSR melalui media akan meningkatkan reputasi perusahaan di mata masyarakat (Harmoni, 2010). Dalam praktiknya, hal ini adalah apa yang menjadi bagian penting dari proses membangun dan membentuk norma-norma atau nilai-nilai yang diterima di masyarakat. Media memiliki peran sebagai penghubung perusahaan untuk mendorong pengelolaan 
pengungkapan CSR dan perusahaan yang ingin mendapatkan kepercayaan dengan legitimasi masyarakat sosial melalui kegiatan CSR (Hasnia \& Rofingatun, 2017). Oleh karena itu, perusahaan harus memiliki kapasitas untuk memenuhi kebutuhan stakeholder dan dapat berkomunikasi dengan pemangku kepentingan secara efektif. Hal ini sejalan dengan enelitian Ekowati et al. (2014) dan Melati (2014) tentang perusahaan manufaktur yang terdaftar di Bursa Efek Indonesia menjelaskan bahwa ada hubungan positif antara media exposure untuk CSR. Berdasarkan uraian di atas, penelitian ini mengusulkan hipotesis kelima sebagai berikut.

$\mathrm{H}_{5}$ : Media Exposure berpengaruh positif pada Pengungkapan CSR.

\section{METODE PENELITIAN}

Ruang lingkup atau lokasi yang digunakan dalam penelitian ini adalah semua perusahaan industri pertambangan yang terdaftar di Bursa Efek Indonesia 20132017. Penentuan sampel dalam penelitian ini menggunakan metode purposive sampling, yaitu teknik sampling dengan kriteria tertentu. Sampel yang digunakan adalah perusahaan pertambangan yang terdaftar di Bursa Efek Indonesia pada 2013-2017.

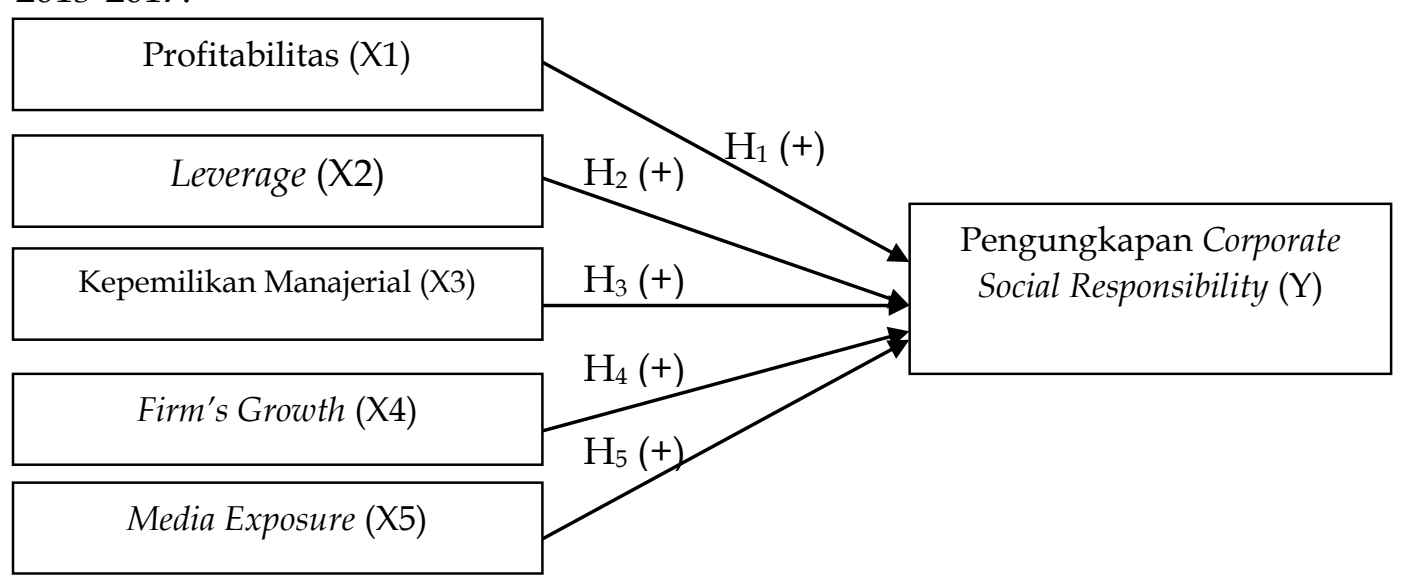

Sumber: Data Penelitian, 2019

Gambar 1. Kerangka Konseptual

Gambar 1. menjelaskan kerangka konseptual penelitian yang dapat dideskripsikan sebagai arah penelitian dan hubungan tiap-tiap variabel independen terhadap variabel dependen yang diteliti. Dalam penelitian ini diteliti hubungan variabel independen (profitabilitas, leverage, kepemilikan manajerial, firm's growth, dan media exposure terhadap variabel dependen (Pengungkapan Corporate Social Responsibility).

Berdasarkan jenisnya, data yang digunakan dalam penelitian adalah data kuantitatif, yaitu data yang berupa angka atau data kualitatif yang menduga (Sugiyono, 2017). Data kuantitatif dalam penelitian ini adalah angka yang digunakan dalam menghitung rasio profitabilitas, leverage, persentase kepemilikan manajerial, firm's growth, media exposure dan pengungkapan CSR yang diperoleh dalam laporan tahunan dan dipublikasikan di situs resmi Bursa Efek Indonesia. Rasio profitabilitas yang digunakan dalam penelitian ini adalah Return on Assets (ROA) yaitu rasio yang mengukur tingkat laba bersih yang diperoleh dari total aset perusahaan. Leverage diukur dengan Debt to Equity Ratio 
(DER) yaitu rasio utang terhadap ekuitas perusahaan. Firm's frowth diukur dengan rasio pertumbuhan perusahaan. Kepemilikan manajerial diukur dengan rasio jumlah saham milik manajer terhadap total saham keseluruhan. Pengukuran variabel media exposuredilakukan dengan variabel dummy, yang berarti dengan menetapkan nilai 1 untuk perusahaan yang mengungkapkan kegiatan CSR di website perusahaan dan 0 untuk perusahaan yang tidak mengungkapkan kegiatan CSR di website perusahaan.

Variabel terikat pada penelitian ini adalah pengungkapan tanggung jawab sosial perusahaan. Variabel ini diukur berdasarkan data yang terdapat dalam laporan tahunan perusahaan. Pengukuran mengacu pada indikator ISO 26000 yaitu sebanyak 50 indikator yang meliputi 7 Core Subjectspengungkapan CSR. Pengungkapan sosial menunjukkanseberapa luas butir-butir pengungkapan yang disyaratkan telah diungkapkan.Pengukuran luas pengungkapan CSR dalam penelitian ini dilakukan secaranon repeated yang artinya hanya menghitung satu kali untuk tiap item tanpamempertimbangkan item tersebut diungkapkan lagi pada halaman atau bagianlain dengan bahasa yang berbeda. Gambar 1 dapat dijelaskan sebagai adanya pengaruh profitabilitas, leverage, kepemilikan manajerial, firm's growth dan media exposure terhadap pengungkapan CSR perusahaan. Dimana semakin tinggi profitabilitas, leverage, kepemilikan manajerial, firm's growth dan media exposure, semakin tinggi pula pengungkapan CSR perusahaan.

Dalam penelitian ini, analisis yang digunakan adalah analisis kuantitatif dengan menggunakan perhitungan statistik dengan bantuan software Statistical Package for Sosial Science (SPSS). Sebelum penelitian ini menggunakan model regresi untuk menguji hipotesis, terlebih dahulu digunakan pengujian asumsi klasik ntuk menilai apakah ada masalah asumsi klasik dalam sebuah model regresi, diantaranya melakukan uji normalitas, uji multikolinearitas, uji heteroskedastisitas, dan uji autokolerasi.Pengujian hipotesis dilakukan dengan analisis regresi berganda, menggunakan alat statistik SPSS dengan signifikansi $0,05(\alpha=5 \%)$. Pengujian hipotesis dengan analisis linear berganda dirumuskan sebagai berikut.

$$
\begin{aligned}
& \mathrm{CSRD}=\alpha+\beta 1 \mathrm{ROA}+\beta 2 \mathrm{DER}+\beta 3 \mathrm{MO}+\beta 4 \mathrm{FG}+\beta 5 \mathrm{ME}+\mathrm{e} \\
& \text { Keterangan: } \\
& \text { CSRD } \\
& \text { = Pengungkapan Tanggung Jawab Sosial } \\
& \text { Perusahaan } \\
& \text { a } \\
& \beta 1, \beta 2, \beta 3, \beta 4, \beta 5 \\
& \text { ROA } \\
& \text { = Konstanta } \\
& =\text { Koefisien Regresi } \\
& =\text { Return on Assets (profitabilitas) } \\
& \text { DER } \\
& \text { = Debt to Equity Ratio (leverage) } \\
& \text { MO = Kepemilikan Manajerial } \\
& \text { FG = Firm's Growth } \\
& \mathrm{ME} \quad=\text { Media Exposure } \\
& \text { e } \quad=\text { Model Kesalahan Term (Residual Variable) }
\end{aligned}
$$

Menurut Ghozali \& Chariri (2007 ) penentuan fungsi regresi sampel dalam memperkirakan nilai aktual dapat diukur dari goodness of fit. Secara statistik, dapat dilihat dari nilai koefisien determinasi (Adjusted $R^{2}$ ), nilai $\mathrm{F}$ 
statistik (model uji kelayakan), dan nilai statistik $\mathrm{t}$ (uji signifikansi parameter individual).

\section{HASIL DAN PEMBAHASAN}

Penelitian ini menggunakan sampel perusahaan pertambangan yang terdaftar di Bursa Efek Indonesia (BEI) selama tahun 2013-2017. Berdasarkan hasil seleksi diperoleh jumlah sampel sebanyak 13 perusahaan dari 42 perusahaan yang terdaftar di BEI. Proses pemilihan sampel dalam penelitian disajikan pada Tabel 1. Proses pemilihan sampel dilakukan dengan teknik purposive sampling yang merupakan salah satu teknik sampling non random sampling dimana dalam menentukan pengambilan sampel dilakukan dengan cara menetapkan ciri atau syarat khusus yang sesuai dengan tujuan penelitian sehingga dapat menjawab permasalahan penelitian atau rumusan masalah yang telah ditentukan.

Tabel 1. Penentuan Sampel Penelitian

\begin{tabular}{lc}
\hline \multicolumn{1}{c}{ Keterangan } & Jumlah \\
\hline Jumlah Populasi & 42 \\
Jumlah perusahaan pertambangan yang tidak mengungkapkan CSR & $(19)$ \\
periode 2013-2017 berturut-turut & \\
$\begin{array}{l}\text { Jumlah perusahaan pertambangan yang tidak menerbitkan laporan } \\
\text { keuangan periode 2013-2017 berturut-turut }\end{array}$ & $(10)$ \\
$\begin{array}{l}\text { Jumlah perusahaan yang mengungkapkan CSR dan laporan keuangan } \\
\text { periode 2013-2017 berturut-turut }\end{array}$ & 13 \\
Jumlah perusahaan yang digunakan sebagai sampel & 13 \\
\hline
\end{tabular}

Sumber: Data Penelitian, 2019

Berdasarkan Tabel 2. terdapat informasi tentang objek penelitian yaitu jumlah data penelitian 65 sampel.

Tabel 2. Statistik Deskriptif

\begin{tabular}{lrrrrr}
\hline & N & Minimum & Maximum & Mean & \multicolumn{1}{c}{$\begin{array}{c}\text { Std. } \\
\text { Deviation }\end{array}$} \\
\hline X1 & 65 & 0,002 & 0,394 & 0,08523 & 0,067422 \\
X2 & 65 & 1,047 & 1,126 & 1,09045 & 0,016260 \\
X3 & 65 & 0,056 & 0,670 & 0,33331 & 0,199572 \\
X4 & 65 & 0,011 & 0,494 & 0,16205 & 0,106268 \\
X5 & 65 & 0,00 & 1,00 & 0,7692 & 0,42460 \\
Y & 65 & 0,020 & 0,710 & 0,36354 & 0,145295 \\
Valid N (litwise) & 65 & & & & \\
\hline
\end{tabular}

Sumber: Data Penelitian, 2019

Variabel independen profitabilitas (X1) menunjukkan rata-rata (mean) sebesar 0,08523 dengan standar deviasi 0,067422 dan nilai maksimum minimum berturut-turut 0,394 dan 0,002. Variabel independen leverage (X2) menunjukkan rata-rata sebesar 1,09045 dengan standar deviasi 0,016260 dan nilai maksimum minimum berturut-turut 1,126 dan 1,047. Variabel independen kepemilikan manajerial (X3) menunjukkan rata-rata sebesar 0,33331 dengan standar deviasi 0,199572 dan nilai maksimum minimum berturut-turut 0,670 dan 0,056. Variabel independen firm's growth (X4) menunjukkan rata-rata sebesar 0,16205 dengan standar deviasi 0,106268 dan nilai maksimum minimum berturut-turut 0,494 dan 0,011. Variabel independen media exposure(X5) menunjukkan rata-rata sebesar 0,7692 dengan standar deviasi 0,42460 dan nilai maksimum minimum berturut- 
turut 1,00 dan 0,00 dengan kecenderungan lebih banyak perusahaan mengungkapkan kegiatan csr melalui media online perusahaan. Variabel dependen Corporate Social Responsibility Disclosure (Y) menunjukkan rata-rata sebesar 0,36354 dengan standar deviasi 0,145295 dan nilai maksimum minimum berturut-turut 0,710 dan 0,020 .

Tabel 3. Uji Normalitas

\begin{tabular}{|c|c|}
\hline & Unstandardized Residual \\
\hline $\mathrm{N}$ & 65 \\
\hline Normal Parameters $\mathrm{a}, \mathrm{b}$ Mean & 0,0000000 \\
\hline Std. Deviation & 0,0026372 \\
\hline Most Extreme & 0,076 \\
\hline Differences & 0,076 \\
\hline Negative & $-0,054$ \\
\hline Kolmogorov-Smirnov Z & 0,609 \\
\hline Asymp. Sig (2-tailed) & 0,852 \\
\hline
\end{tabular}

Sumber: Data Penelitian, 2019

Berdasarkan tabel 3,model regresi yang digunakan dalam penelitian ini memiliki data yang terdistribusi normal. Hal ini dapat dilihat dari nilai Asymp. Sig. (2-tailed) yaitu 0,852 yang bernilai lebih besar dari 0,05.

Tabel 4. Uji Multikolinearitas

\begin{tabular}{cccc}
\hline & Model & \multicolumn{2}{c}{ Collinearity Statistics } \\
\cline { 3 - 4 } & X1 & Tolerance & VIF \\
\hline 1 & X2 & 0,806 & 1,241 \\
& X3 & 0,932 & 1,073 \\
& X4 & 0,83 & 1,204 \\
& X5 & 0,908 & 1,102 \\
& & 0,875 & 1,143 \\
\hline
\end{tabular}

Sumber: Data Penelitian, 2019

Berdasarkan tabel 4, model regresi yang digunakan dalam penelitian ini tidak mengalami gejala multikolinearitas. Hal ini terlihat pada nilai tolerance seluruh variabel bebas lebih besar dari 0,1 dan nilai VIF seluruh variabel bebas lebih kecil dari 10.

Tabel 5. Uji Autokolerasi

\begin{tabular}{lrrrrr}
\hline Model & R & R Square & $\begin{array}{l}\text { Adjusted R } \\
\text { square }\end{array}$ & $\begin{array}{l}\text { Std. Error of the } \\
\text { Estimate }\end{array}$ & Durbin- Watson \\
\hline 1 & $0,900^{\mathrm{a}}$ & 0,810 & 0,803 & 0,002743 & 1,848 \\
\hline
\end{tabular}

Sumber: Data Penelitian, 2019

Berdasarkan tabel 5, diperoleh nilai du sebesar 1,7311 dan nilai 4-du sebesar 2,2689. Nilai Durbin-Waston penelitian sebesar1,848 lebih besar daripada nilai du sebesar 1,7311 dan lebih kecil daripada nilai 4-du sebesar 2,2689, sehingga model regresi yang digunakan dalam penelitian tidak mengandung gejala autokorelasi.

Tabel 6. Uji Heteroskedastisitas

\begin{tabular}{cccccc}
\hline \multirow{2}{*}{ Model } & \multicolumn{2}{c}{ Unstandardized Coefficients } & \multicolumn{2}{c}{ Standardized Coefficients } & \multirow{2}{*}{ Sig } \\
\cline { 2 - 4 } & $\mathrm{B}$ & Std. Error & Beta & $\mathrm{T}$ & \\
\hline 1 (Constant) & $-0,016$ & 0,013 & & $-1,194$ & 0,237 \\
X1 & 0,006 & 0,003 & 0,276 & 2,001 & 0,051 \\
X2 & 0,016 & 0,012 & 0,167 & 0,060 & 0,199 \\
\hline
\end{tabular}


Lanjutan Tabel 6.

\begin{tabular}{lccccc} 
X3 & 0,000 & 0,001 & 0,060 & $-0,040$ & 0,659 \\
X4 & $-0,001$ & 0,002 & $-0,040$ & 0,083 & 0,761 \\
X5 & 0,000 & 0,000 & 0,083 & 0,629 & 0,532 \\
\hline
\end{tabular}

Sumber: Data Penelitian, 2019

Berdasarkan Tabel 6. diketahui bahwa model regresi penelitian ini tidak mengalami masalah heteroskedastisitas karena nilai sig. masing-masing variabel lebih besar dari 0,05 dimana nilai sig. X1 $(0,051)>a(0,05)$; nilai sig.X2 $(0,199)>a$ $(0,05)$; nilai sig. X3 $(0,659)>$ a $(0,05)$; nilai sig. X4 $(0,761)>$ a $(0,05)$; dan nilai sig X5 $(0,532)>$ a $(0,05)$. Sehingga dapat disimpulkan bahwa model ini tidak mengalami masalah heteroskedastisitas.

Berdasarkan uji asumsi klasik, diketahui bahwa data dalam penelitian ini terdistribusi normal, tidak ada autukolerasi, bebas multikolinearitas, dan tidak terjadi heteroskedasitisitas. Sehingga, data yang tersedia telah memenuhi syarat untuk lanjut menggunakan model regresi linear berganda.

Pengujian hipotesis dalam penelitian ini menggunakan analisis regresi berganda untuk menguji pengaruh masing-masing variabel bebas terhadap Corporate Social Responsibility Disclosure (y). Ringkasan hasil regresi berganda disajikan pada Tabel 7.

Tabel 7. Uji Regresi Berganda

\begin{tabular}{cccccc}
\hline \multirow{2}{*}{ Model } & \multicolumn{2}{c}{ Unstandardized Coefficients } & \multicolumn{2}{c}{ Standardized Coefficients } & \multirow{2}{*}{ Sig } \\
\cline { 2 - 4 } & $\mathrm{B}$ & Std. Error & Beta & $\mathrm{T}$ & \\
\hline 1 (Constant) & $-0,016$ & 0,013 & & $-1,194$ & 0,237 \\
X1 & 0,006 & 0,003 & 0,276 & 2,001 & 0,051 \\
X2 & 0,016 & 0,012 & 0,167 & 0,060 & 0,199 \\
X3 & 0,000 & 0,001 & 0,060 & $-0,040$ & 0,659 \\
X4 & $-0,001$ & 0,002 & $-0,040$ & 0,083 & 0,761 \\
X5 & 0,000 & 0,000 & 0,083 & 0,629 & 0,532 \\
\hline
\end{tabular}

Sumber: Data Penelitian, 2019

berikut:

Hasil uji regresi pada tabel 7. diperoleh persamaan regresi sebagai

$$
\mathrm{Y}=-0,589+0,295 \mathrm{X} 1+0,473 \mathrm{X} 2+0,398 \mathrm{X} 3+0,306 \mathrm{X} 4+0,299 \mathrm{X} 5+\mathrm{e}
$$

Dimana persamaan regresi tersebut memiliki makna seberapa besar atau signifikan persentase masing-masing variabel independen $(X)$ memengaruhi variabel dependen $(\mathrm{Y})$ dengan anotasi e sebagai residual variable. Nilai koefisien regresi profitabilitas $\left(X_{1}\right)$ adalah 0,295 . Memiliki arti apabila profitabilitas meningkat 1\% (variabel lain dianggap konstan), maka pengungkapan CSR akan mengalami peningkatan sebesar $29,5 \%$. Nilai koefisien regresi leverage $\left(X_{2}\right)$ adalah 0,473 . Memiliki arti apabila leverage meningkat $1 \%$ (variabel lain dianggap konstan), maka pengungkapan CSR akan mengalami peningkatan sebesar 47,3\%.Nilai koefisien regresi kepemilikan manajerial $\left(\mathrm{X}_{3}\right)$ adalah 0,398. Memiliki arti apabila kepemilikan manajerial meningkat 1\% (variabel lain dianggap konstan), maka pengungkapan CSR akan mengalami peningkatan sebesar $39,8 \%$.Nilai koefisien regresi firm's growth $\left(X_{4}\right)$ adalah 0,306 . Memiliki arti apabila firm's growth meningkat $1 \%$ (variabel lain dianggap konstan), maka pengungkapan CSR akan mengalami peningkatan sebesar 30,6\%.Nilai koefisien regresi media exposure $\left(\mathrm{X}_{5}\right)$ adalah 0,299 . Memiliki arti apabila media exposure meningkat 1\% (variabel lain dianggap konstan), maka pengungkapan CSR akan 
mengalami peningkatan sebesar $29,9 \%$. Nilai konstanta sebesar $-0,589$ memiliki arti apabila semua variabel independen konstan, maka pengungkapan CSR adalah sebesar $-0,589$.

\section{Tabel 8. Uji Koefisien Determinasi}

\begin{tabular}{ccccc}
\hline Model & $\mathrm{R}$ & R Square & $\begin{array}{c}\text { Adjusted R } \\
\text { Square }\end{array}$ & $\begin{array}{c}\text { Std. Error of the } \\
\text { Estimate }\end{array}$ \\
\hline 1 &, 900 (a) &, 810 &, 803 &, 002743 \\
\hline
\end{tabular}

Sumber: Data Penelitian, 2019

Berdasarkan tabel 8, nilai Adjusted $R^{2}$ pada model regresi sebesar 0,803. Maka, sebesar $80,3 \%$ variasi corporate social responsibility disclosure dapat dijelaskan oleh profitabilitas (ROA), leverage (DER), Kepemilikan Manajemen, Pertumbuhan Perusahaan dan Media Exposure sedangkan sisanya sebesar 19,7\% dijelaskan oleh variabel lain di luar model penelitian ini.

Tabel 9. Uji Kelayakan Model

\begin{tabular}{|c|c|c|c|c|c|}
\hline Model & Sum of Squares & $\mathrm{Df}$ & Mean Square & $\mathrm{F}$ & Sig \\
\hline Regression & 1,351 & 5 & ,270 & 35900,599 &, $000^{\mathrm{a}}$ \\
\hline Residual & ,000 & 59 & , 000 & & \\
\hline Total & 1,351 & 64 & & & \\
\hline
\end{tabular}

Sumber: Data Penelitian, 2019

Berdasarkan tabel 9,nilai $F$ sebesar35900,599 $>\mathrm{df}(5 ; 65)=2,37$ dengan probabilitas (Sig) sebesar 0,000 $<a=0,05$ yang berarti bahwa variabel bebas dalam penelitian ini berpengaruh dan dapat menjelaskan variabel terikatnya secara simultan, sehingga model ini layak untuk diujikan dan pembuktian hipotesis dapat dilakukan.

Pembuktian hipotesis dilakukan menggunakan uji t pada tabel 7. Hasil analis regresi linier berganda pengaruh profitabilitas pada pengungkapan CSR perusahaan pada tabel 7. diketahui nilai signifikansi (Sig) variabel profitabilitas (X1) adalah sebesar 0,000. Karena nilai Sig. 0,000 < probabilitas 0,05, maka dapat disimpulkan bahwa $\mathrm{H} 1$ atau hipotesis pertama diterima. Artinya profitabilitas (X1) berpengaruh positif pada Corporate Social Responsibility Disclosure (Y).Profitabilitas perusahaan memberikan indikasi tentang efektivitas manajemen perusahaan. Hal ini sangat mungkin untuk melihat perusahaan yang menguntungkan memberikan informasi rinci dalam rangka untuk menarik investor dan untuk menyoroti efektivitas manajemen. Perusahaan yang menguntungkan memiliki sinyal positif terhadap stakeholders. Oleh karena itu, dapat dimengerti perusahaan profitable akan cenderung mengungkapkan informasi lebih dari perusahaan non-profitable.

Hasil penelitain ini sejalan dengan sebagian besar penelitian sebelumnya antara lain penelitian yang dilakukan oleh Hassan \& Naser (2013) dan Felicia \& Rasmini (2015) melaporkan hubungan positif dan signifikan antara tingkat pelaporan tanggung jawab sosial perusahaan dan profitabilitas perusahaan. Hal ini dikarenakan profitabilitas merupakan faktor utama penilaian investor terhadap perusahaan, yang bisa dilihat dari seberapa besar laba yang dihasilkan perusahaan. Kondisi ini mendukung teori Signaling dimana melalui laporan keuangan, stakeholders atau pihak yang berkepentingan dapat menilai item yang terdapat dalam laporan keuangan tersebut sebagai suatu sinyal dalam upaya pengambilan suatu keputusan yang dalam konteks ini profitabilitas dan 
pengungkapan CSR memberikan suatu sinyal kepada investor dalam pengambilan suatu keputusan investas i(Sabatini \& Sudana, 2019).

Berdasarkan Tabel 7. diketahui nilai signifikansi (Sig) variabel leverage (X2) adalah sebesar 0,000. Karena nilai Sig. 0,000 < probabilitas 0,05, maka dapat disimpulkan bahwa $\mathrm{H} 2$ atau hipotesis kedua diterima. Artinya leverage (X2) berpengaruh positif pada Corporate Social Responsibility Disclosure (Y). Sebuah perusahaan high leveraged akan diminta oleh pemberi pinjaman untuk mengungkapkan informasi lebih rinci daripada perusahaan dengan rasio leverage yang rendah. Pemberi pinjaman meminta informasi rinci sebelum memberikan pinjaman. Hasil penelitian ini mendukung teori Signaling dimana informasi seperti informasi finansial (angka termuat dalam laporan keuangan dan tahunan) dan non finansial (pengungkapan CSR) merupakan informasi yang dapat memberikan sinyal kepada pemberi pinjaman. Selain itu, bank dan organisasi pinjaman lainnya lebih cenderung untuk meminjamkan perusahaan yang sukses dan terkemuka. Oleh karena itu, perusahaan yang high leveraged sangat mungkin untuk mengungkapkan informasi lebih dari perusahaan lainnya untuk memenuhi harapan bank dan harapan organisasi pinjaman lainnya sehingga perusahaan demi melakukan usahanya mendapatkan legitimasi dari stakeholders yang kemudian akan mendorong pelaporan CSR itu sendiri.

Hal ini sejalan dengan sebagian besar dari studi sebelumnya seperti penelitian yang dilakukan oleh Felicia \& Rasmini (2015) menunjukkan hubungan yang positif dan signifikan antara tingkat pelaporan tanggung jawab sosial perusahaan dan tingkat leverage perusahaan.

Berdasarkan tabel 7. diketahui nilai signifikansi (Sig) variabel kepemilikan manajemen (X3) adalah sebesar 0,000. Karena nilai Sig. 0,000 < probabilitas 0,05, maka dapat disimpulkan bahwa $\mathrm{H3}$ atau hipotesis ketiga diterima. Artinya kepemilikan manajemen (X3) berpengaruh positif pada Corporate Social Responsibility Disclosure (Y). Semakin besar kepemilikan manajer dalam perusahaan maka lebih produktif tindakan manajer dalam memaksimalkan nilai perusahaan, dengan kata lain, kontrak dan pengawasan biaya menjadi rendah serta pengungkapan CSR meningkat. Hasil penelitian ini mendukung teori Atribusi yang menjelaskan tentang perilaku seseorang atas kondisi atau kejadian di sekitar mereka. Pada dasarnya karakteristik personal seorang manajer merupakan salah satu penentu terhadap kualitas pengungkapan CSR yang akan dilakukan karena merupakan suatu faktor internal yang mendorong seseorang untuk melakukan suatu aktivitas yang dalam hal ini semakin besar kepemilikan manajemen dalam perusahaan maka semakin produktif manajer dalam memaksimalkan nilai perusahaan melalui pengungkapkan informasi-informasi CSR yang lebih rinci.

Hal ini sejalan dengan penelitian Mahadewi \& Krisnadewi (2017) menunjukkan bahwa kepemilikan manajerial secara positif memengaruhi hubungan antara kepemilikan saham manajerial atas pengungkapan CSR yang luas. Hal yang sama juga disampaikan Rahajeng (2010) bahwa kepemilikan saham manajerial memengaruhi pengungkapan CSR di Indonesia.

Berdasarkan tabel 7. diketahui nilai signifikansi (Sig) variabel firm's growth (X4) adalah sebesar 0,000. Karena nilai Sig. 0,000 < probabilitas 0,05, maka dapat disimpulkan bahwa $\mathrm{H} 4$ atau hipotesis keempat diterima. Artinya firm's 
growth (X4) berpengaruh positif pada Corporate Social Responsibility Disclosure (Y). Pertumbuhan perusahaan merupakan salah satu indikator pertimbangan dalam berinvestasi. Perusahaan yang memiliki peluang pertumbuhan yang tinggi diharapkan dapat memberikan keuntungan yang tinggi di masa mendatang, pendapatan diharapkan lebih tinggi, sehingga investor akan tertarik untuk berinvestasi di perusahaan (Aryani, 2011). Perusahaan dengan pertumbuhan yang tinggi akan mendapatkan banyak perhatian sehingga diprediksi perusahaan yang memiliki peluang pertumbuhan yang lebih tinggi cenderung melakukan Corporate Social Responsibility Disclosure. Penelitian ini mendukung teori legitimasi sekaligus teori signaling dimana ketika perusahaan mendapatkan sorotan atau perhatian dari stakeholders maka perusahaan tersebut cenderung mengungkapkan CSR dan pengungkapan lainnya secara lebih rinci, hal ini dilakukan untuk mendapatkan legitimasi dari stakeholders dimana perusahaan dalam menjalankan usahanya harus sesuai dengan norma yang berlaku dan memberikan sinyal positif kepada stakeholders yang juga mendukung teori signaling. Semakin tinggi firm's growth maka diharapkan memberikan keuntungan yang tinggi kepada investor dalam upaya pengambilan keputusan investasi. Penelitian ini sejalan dengan penelitian Munsaidah et al.(2016) dimana pertumbuhan perusahaan berpengaruh terhadap pengungkapan CSR.

Berdasarkan tabel 7. diketahui nilai signifikansi (Sig) variabel media exposure (X5) adalah sebesar 0,000. Karena nilai Sig. 0,000 < probabilitas 0,05, maka dapat disimpulkan bahwa $\mathrm{H} 5$ atau hipotesis kelima diterima. Artinya media exposure (X5) berpengaruh positif pada Corporate Social Responsibility Disclosure (Y). Fungsi komunikasi menjadi hal yang sangat penting dalam manajemen pengungkapan CSR. Komunikasi CSR melalui media akan meningkatkan reputasi perusahaan di mata masyarakat. Dalam praktiknya, ini adalah apa yang menjadi bagian penting dari proses membangun dan membentuk norma-norma atau nilai-nilai yang diterima di masyarakat. Hasil penelitian ini didukung oleh teori legitimasi dimana media memiliki peran sebagai penghubung perusahaan untuk mendorong pengelolaan pengungkapan CSR dan perusahaan yang ingin mendapatkan kepercayaan dengan legitimasi masyarakat sosial melalui kegiatan CSR. Semakin besar dorongan atau sorotan media pada suatu perusahaan maka semakin tinggi pengungkapan CSR yang dilakukan suatu perusahaan karena sorotan media merupakan suatu dorongan atau tekanan kepada perusahaan agar perusahaan menjalankan usahanya sesuai dengan nilai-nilai yang diterima di masyarakat dan tidak hanya mementingkan perusahaan saja ketika melakukan usahanya karena perusahaan juga merupakan bagian dari komunitas masyarakat.

Hal ini sejalan dengan penelitian yang dilakukan oleh Ekowati (2014) yang meneliti perusahaan manufaktur yang terdaftar di Bursa Efek Indonesia menjelaskan bahwa ada hubungan positif antar paparan media (media exposure) pada pengungkapan tanggung jawab sosial perusahaan.

\section{SIMPULAN}

Variabel profitabilitas yang diukur dengan Return on Asset (ROA) berpengaruh positif terhadap variabel pengungkapan Corporate Social Responsibility. Hal ini dapat dijelaskan dengan argumen bahwa perusahaan yang memiliki laba yang 
tinggi akan menjadi sorotan.Untuk mengurangi tekanan tersebut, perusahaan akan mengeluarkan biaya yang berkaitan dengan tanggung jawab sosial sehingga dapat dimengerti bahwa perusahaan profitable cenderung mengungkapkan informasi sosial lebih banyak dan detail daripada perusahaan non-profitable.

Variabel leverageyang diukur dengan Debt to Equity Ratio (DER) berpengaruh positif terhadap variabelpengungkapan Corporate Social Responsibility. Hal ini dapat dijelaskan dengan argumen bahwa perusahaan yang memiliki tingkat utang yang tinggi akan mendapat sorotan. Selain itu, bank dan organisasi pinjaman lainnya lebih cenderung untuk meminjamkan dana kepada perusahaan yang sukses dan terkemuka. Oleh karena itu, perusahaanhigh levereged sangat mungkin untuk mengungkapkan informasi lebih dari perusahaan lainnya untuk memenuhi harapan organisasi pinjaman. Hubungan yang tetap terjalin dengan baik antara perusahaan dan debtholders dapat mengurangi sorotan publik terhadap perusahaan.

Variabel kepemilikan manajemen perusahaan yang diukur dengan persentase jenis kepemilikan manajerial berpengaruh positif terhadap variabel pengungkapan Corporate Social Responsibility. Hal ini dapat dijelaskan dengan argumen bahwa semakin besar proporsi kemepemilikan manajemen dalam perusahaan, manajemen cenderung berusaha lebih untuk kepentingan pemegang saham,yaitu dirinya sendiri. Manajer perusahaan akan mengungkapkaninformasi sosial dalam rangka meningkatkan citra perusahaan.

Variabel firm's growth yang diukur dengan rasio pertumbuhan penjualan berpengaruh positif terhadap variabel pengungkapan Corporate Social Responsibility.Hal ini dapat dijelaskan dengan argumen bahwa investor lebih tertarik dengan perusahaan yang memiliki peluang pertumbuhan yang tinggi. Selain itu, investor berharap agar perusahaan tersebut memberikan keuntungan yang tinggi pada masa mendatang. Perusahaan dengan pertumbuhan yang lebih tinggi cenderung mendapatkan banyak perhatian sehingga akan melaporkan Corporate Social Responsibility Disclosure.

Variabel media exposure yang diukur dengan variabel dummy dengan anotasi 1 untuk perusahaan yang mengungkapkan informasi CSR melalui media perusahaan, sedangkan 0 untuk yang tidak mengungkapkan informasi CSR melalui media perusahaanberpengaruh positif terhadap pengungkapan Corporate Social Responsibility. Hal ini dapat dijelaskan dengan argumen bahwa media memiliki peran sebagai penghubung perusahaan untuk mendorong pengelolaan pengungkapan CSRdan perusahaan yang ingin mendapatkan kepercayaan dan legitimasi masyarakat luas melalui kegiatan CSR.Oleh karena itu, perusahaan harus memiliki kapasitas untuk memenuhi kebutuhan stakeholders dan dapat berkomunikasi dengan pemangku kepentingan secara efektif dengan cara melaporkanpengungkapan CSR secara detail, baik dalam media perusahaan maupun laporan keuangan atau annual report.

Bagi peneliti selanjutnya yang tertarik untuk melakukan penelitian sejenis disarankan untuk mempertimbangkan jumlah sampel yang lebih besar atau sampel dengan perusahaan selain perusahaan pertambangan. Selain itu, penelitian selanjutnya juga dapat mengembangkan faktor-faktor lain yang berkaitan dengan pengungkapan CSR seperti umur perusahaan, kepemilikan 
publik, dan kepemilikan asing. Bagi pihak manajemen perusahaan diharapkan agar lebih mengungkapkan hal-hal yang berhubungan dengan Corporate Social Responsibility Disclosure secara lebih detail dan lengkap dalam laporan tahunannya, hal ini bertujuan sebagai bentuk jaminan pada pihak eksternal khususnya stakeholders atau pihak yang berkepentingan lainnya. Bagi investor hendaknya menilai perusahaan tidak hanya pada aspek ekonomi perusahaan saja, tetapi juga harus memertimbangkan bagaimana perusahaan tersebut peduli pada sosial dan lingkungan, sehingga investor akan turut andil dalam menjaga keberlanjutan sosial, ekonomi dan lingkungan.

\section{REFERENSI}

Ajilaksana, I. D. K. Y. (2011). Pengaruh Corporate Social Responsibility Terhadap Kinerja Keuangan Perusahaan. Skripsi. Sarjana Jurusan Akuntansi Fakultas Ekonomi Universitas Diponegoro.

Aryani, E. R. (2011). Pengaruh Good Corporate Governance Dan Struktur Kepemilikan Terhadap Agency Cost. Skripsi. Sarjana Jurusa Akuntansi Fakultas Ekonomi Universitas Diponegoro.

Cowen, S. S. (1987). The Impact of Corporate Characteristics on Social Responsibility Disclosure: A Typology and Frequency-Based Analysis. Accounting, Organisations and Society, 12(2), 111-122.

Ekowati. (2014). Pengaruh Profitabilitas, Likuiditas, Pertumbuhan, dan Media Exposure pada Pengungkapan Corporate Social Responsibility. Simposium Nasional Akuntansi XVII.

Epstein, M. J., \& Friedman, M. (1994). Social Disclosure and the Individual Investor. Accounting, Auditing \& Accountability Journal, 7(4), 94-109.

Felicia, M., \& Rasmini, N. K. (2015). Faktor-Faktor Yang Mempengaruhi Pengungkapan Corporate Social Responsibility Pada Perusahaan Yang Fakultas Ekonomi Dan Bisnis, Universitas Udayana ( Unud ), Bali , Indonesia Jurusan Ekonomi Dan Bisnis, Fakultas Ekonomi Dan Bisnis, Universitas Pendahulu. E-Jurnal Akuntansi Universitas Udayana, 12(2), 143153.

Retrieved

from https://ojs.unud.ac.id/index.php/Akuntansi/article/view/16175/12658

Ghozali, I., \& Chariri. (2007). Teori Akuntansi. Semarang: Badan Penerbit Universitas Diponegoro.

Harmoni, A. (2010). Media Richness Theory dan Potensi Website sebagai Media Komunikasi CSR oleh Perusahaan. Jurnal Ekonomi Dan Bisnis, 15(1), 9-17.

Hasnia, \& Rofingatun, S. (2017). Pengaruh Profitabilitas, Likuiditas, Growth dan Media Exposure terhadap Pengungkapan Tanggung Jawab Sosial Perusahaan (Studi Empiris pada Perusahaan Manufaktur dan Perusahaan Jasa yang Terdaftar di Bursa Efek Indonesia Tahun 2013-2015). Jurnal Akuntansi \& Keuangan Daerah, 12(2014), 56-71.

Hassan, \& Naser, K. (2013). The Influence of CSR on Performance and Its Determinants in Listed Companies in Indonesia. Jurnal Isu Kontemporer Dalam Bisnis Riset, 2(3), 56-74.

Jogiyanto, H. (2017). Teori Portofolio dan Analisis Investasi. Yogyakarta: BPFE.

Kholis, A., \& Maksum, A. (2003). Analisis Pentingnya Tanggung Jawab dan Perusahaan Akuntansi Sosia. Media Riset Akuntansi, Auditing \& Informasi, 
$3(2), 101-132$.

Mahadewi, A. A. I. S., \& Krisnadewi, K. A. (2017). Pengaruh Kepemilikan Manajerial, Institusional dan Proporsi Dewan Komisaris Independen pada Manajemen Laba. E-Jurnal Akuntansi Universitas Udayana, 18(1), 443-470.

Maria, U. (2009). Pengaruh Karakteristik Perusahaan terhadap Corporate Social Responsibility Disclosure. Skripsi. Sarjana Jurusan Akuntansi Fakultas Ekonomi Universitas Islam Indonesia.

Melati, P. (2014). Faktor-faktor Yang Mempengaruhi Corporate Social Responsibility (CSR) Studi (Empiris Pada Perusahaan Industri Dasar Dan Kimia Yang Terdaftar Di BEI Periode 2010-2012). Jurnal Ekonomi Universitas MAritim Raja Ali Haji, 3(5), 35-54.

Munsaidah, S., Andini, R., \& Supriyanto, R. (2016). Analisis Pengaruh Firm Size, Age, Profitabilitas, Leverage, dan Growth Perusahaan terhadap Corporate Social Responsibility (Csr) pada Perusahaan Property Dan. Journal $f$ Accounting, 2(2). Retrieved from http://jurnal.unpand.ac.id/index.php/AKS/article/view/471

Nasution, H. N., Mavondo, \& Matanda. (2011). Entrepreneurship-Its Realtionship with Market Orientation and Learning Orientation and As Antecendents to Inovation and Consumer Value. Of Industrial Marketing Management, 40(3), 336-345.

Policy, Y. C. for E. L. \&. (2018). Enviromental Performance Index.

Putra, Y. Y. D., \& Wiagustini, N. L. P. (2013). Pengaruh Likuiditas Dan Leverage Terhadap Profitabilitas Dan Nilai Perusahaan Pada Perusahaan Perbankan Di Bei. Jurnal Wawasan Manajemen, 1(2), 215-232.

Rahajeng, R. G. (2010). Faktor-Faktor yang Mempengaruhi Pengungkapan Sosial (Sosial Disclosure) dalam Laporan Tahunan Perusahaan. Skripsi. Sarjana Fakultas Ekonomi Universitas Diponegoro.

Reni, F., \& Anggraini, R. (2006). Pengungkapan Informasi Sosial dan FaktorFaktor yang Mempengaruhi Pengungkapan Informasi Sosial dalam Laporan Keuangan Tahunan ( Studi Empiris pada Perusahaan-Perusahaan yang terdaftar Bursa Efek Jakarta ). Simposium Nasional Akuntansi IX Padang, 24, 121.

Ross. (2002). Fundamental of Corporate Governance dan Corporate Social Responsibility pada Nilai Perusahaan (5th ed.). Mc Graw-Hill.

Sabatini, K., \& Sudana, I. P. (2019). Pengaruh Pengungkapan Corporate Social Responsibility Pada Nilai Perusahaan Dengan Manajemen Laba Sebagai Variabel Moderasi. Jurnal Ilmiah Akuntansi Dan Bisnis, 14(1), 56-69. https://doi.org/10.24843/jiab.2019.v14.i01.p06

Sari, R. A. (2017). Pengaruh Karakteristik Perusahaan, Disclosure, Terhadap Corporate Social Responsibility Manufaktur, Pada Perusahaan Yang Terdaftar Di Bursa Efek Indonesia. Jurnal Nominal, I(I), 124-140.

Shun-Yu Chen. (2011). Capital structure determinants: An empirical study in Taiwan. African Journal of Business Management, 5(27), 10974-10983. https://doi.org/10.5897/ajbm10.1334

Sugiyono. (2017). Kualitatif Kuantitatif Metode Penelitian dan RND. Bandung: Alfabeta. 